\title{
Communication
}

\section{Decrease in Available Soil Water Storage Capacity Reduces Vitality of Young Understorey European Beeches (Fagus sylvatica L.) - A Case Study from the Black Forest, Germany}

\section{Tamalika Chakraborty $^{1}{ }^{1}$, Somidh Saha ${ }^{2}$ and Albert Reif ${ }^{1}$}

1 Chair of Vegetation Science, Faculty of Environment and Natural Resources,

University of Freiburg, Tennenbacherstr. 4, Freiburg D-79085, Germany;

E-Mail: albert.reif@waldbau.uni-freiburg.de

2 Chair of Silviculture, Faculty of Environment and Natural Resources, University of Freiburg, Tennenbacherstr. 4, Freiburg D-79085, Germany; E-Mail: somidh.saha@waldbau.uni-freiburg.de

* Author to whom correspondence should be addressed; E-Mails: tamalika.chakraborty@waldbau.unifreiburg.de; chakraborty.tamalika@gmail.com.

Received: 27 June 2013; in revised form: 17 September 2013 / Accepted: 10 October 2013 /

Published: 23 October 2013

Abstract: Growth and survival of young European beech (Fagus sylvatica L.) is largely dependent on water availability. We quantified the influence of water stress (measured as Available Soil Water Storage Capacity or ASWSC) on vitality of young beech plants at a dry site. The study site was located in a semi-natural sessile oak (Quercus petraea (Mattuschka) Liebl.) stand adjacent to beech stands on a rocky gneiss outcrop in southwestern Germany. Plant vitality was measured as crown dieback and estimated by the percentage of dead above ground biomass. The magnitude of crown dieback was recorded in different vertical parts of the crown. Biomass was calculated from the harvested plants following allometric regression equations specifically developed for our study site. Stem discs from harvested plants were used for growth analysis. We found that soil depth up to bedrock and skeleton content significantly influenced ASWSC at the study site. A significant negative correlation between ASWSC and crown dieback was found. Highest rates of crown dieback were noticed in the middle and lower crown. The threshold of crown dieback as a function of drought stress for young beech plants was calculated for the first time in this study. This threshold of crown dieback was found to be $40 \%$ of above ground biomass. Beyond $40 \%$ crown dieback, plants eventually experienced complete mortality. In 
addition, we found that the extremely dry year of 2003 significantly hampered growth (basal area increment) of plants in dry plots (ASWSC $<61 \mathrm{~mm}$ ) in the study area. Recovery in the plants' radial growth after that drought year was significantly higher in less dry plots (ASWSC > $61 \mathrm{~mm}$ ) than in dry plots. We concluded that a decrease in ASWSC impeded the vitality of young beech causing partial up to complete crown dieback in the study site.

Keywords: water stress; available soil water storage capacity; crown dieback; above ground biomass; tree survivability; semi-natural forest; summer drought of 2003; basal area increment

\section{Introduction}

The reduction in precipitation and increase of temperature during the growing season in recent years indicates a higher frequency of periodic drought in Central Europe [1]. Climatic data of the last 50 years shows a changing pattern following a positive and negative trend for temperature and precipitation, respectively, in southern Germany [2]. Climate models predict that the frequency of severe summer drought will increase in southern Germany under the scenario of global change that can directly impact forests. For example, the severe summer drought of 2003 reduced the net primary production of beech forest and caused high mortality in the southern part of Central Europe [3]. Trees are more prone to die in dry sites due to water stress in very dry and hot years such as 2003 [4,5]. Water stress can occur due to depletion of soil water and causes damage to plants by inhibiting plant vitality with profound changes in growth and morphology [4,6,7]. Plants' tolerance to drought varies between different species. Past experiments on water stress tolerance in beech plants were carried out under laboratory or greenhouse conditions and found an influence of drought and water availability on beech survival, height and diameter growth [8-11]. The majority of these studies revealed that water stress could significantly reduce growth of beech plants in controlled laboratory conditions and experimental trial plots. In this context, European beech trees (Fagus sylvatica L.) are expected to decline in dry forest sites in the future under the ongoing climate change [12]. However, detailed investigations on the influence of water stress on vitality of young beech plants in dry site conditions at semi-natural forests are rare [5,13,14].

Tree vitality is a complex phenomenon, which is difficult to quantify in forest stands. Therefore, indicators like crown dieback are commonly used to assess it [15]. So far studies on water stress impact in forest stands have commonly assessed crown dieback by morphological classification or defoliation measurement, which are inevitably qualitative in nature [5,16]. However, quantitative assessment of crown dieback in proportion of actual plant biomass has never been carried out in trees grown in forests. Such methods would help to determine the dieback threshold in trees under drought stress. In addition, such information could help scientists and forest managers to assess the carbon loss in forests due to drought induced tree mortality. This crown-dieback threshold in terms of biomass can act as morphological indicator for the plants' internal system failure, which may lead to complete plant death. Therefore, quantification of tree mortality and information on dieback threshold is very important in order to gain knowledge about the success of beech survivability under dry, semi-natural 
conditions in unmanaged forests. This motivated the authors to develop a novel approach to quantitatively assess crown dieback in young European beech plants. We precisely calculated the proportion of living and dead individual tree biomass to quantify crown dieback.

Severe drought events such as the European summer drought of 2003 can significantly reduce growth in beech trees [17]. The magnitude of reduction in radial growth after severe drought and recovery aftermath may fluctuate along the gradient of soil water storage capacity. However, such assumptions had never been tested on young understorey beech plants grown in semi-natural forest condition where human management had been abandoned for many decades. The magnitude of crown dieback is thought to be higher in the upper crown of trees because of higher susceptibility of xylem cavitation in the upper portion of the crown, which eventually leads to failure in hydraulic conductivity and crown dieback [18,19]. In 2005, Kohler et al. first reported the highest amount of dieback in the upper portion of the crown after the severe drought year of 2003 among intermediate beech trees (average height $10 \mathrm{~m}$ ) in southwestern Germany [5]. However, similar assumptions have not been tested on young understorey beech plants with shorter height (e.g., 30-250 cm). Survival of beech plants belonging to this height cohort is crucial for successful natural regeneration in semi-natural forests and maintenance of structural and compositional complexities in forests after abandonment of human management [20].

Therefore, this study aimed to quantify the impact of water stress (measured as soil available water storage capacity or ASWSC) on crown dieback and basal area increment of young beech plants in a semi-natural sessile oak (Quercus petraea (Mattuschka) Liebl.) stand adjacent to beech stands. The stand was a rocky gneiss outcrop located at the Schlossberg hill in the submontane zone of the Black Forest, southwestern Germany. We hypothesized that (1) decreasing ASWSC would increase crown dieback in beech trees; (2) crown dieback would be higher in the upper crown; and (3) growth recovery (increase in basal area increment) would be higher in plants grown in less dry plots (ASWSC > $61 \mathrm{~mm}$ ) than dry plots (ASWSC < $61 \mathrm{~mm}$ ) after the 2003 summer drought. In addition, we aimed to find the important soil parameters that control ASWSC in the study site.

\section{Results}

\subsection{Available Soil Water Storage Capacity (ASWSC) in Stand}

The average stand ASWSC combining all plots was $67.4 \mathrm{~mm}$ (standard error: 7.14). In the linear regression analysis we found that the depth of soil up to bedrock and the soil skeleton content were the most important factors that significantly controlled the soil water storage capacity in our study site. Interestingly, we did not find any significant relationship between slope and ASWSC. Increase in soil depth also increased ASWSC. However, an increase in soil skeleton content decreased ASWSC (see Table 1). 
Table 1. Results from linear regression analysis regarding the influence of soil physical properties and slope on available water storage capacity (ASWSC) (Model $\mathrm{R}^{2}=0.961$, $\mathrm{F}=68.269, d f=6, p<0.0001)$.

\begin{tabular}{ccccc}
\hline Model parameters & Model estimates & Standard error & $\boldsymbol{t}$ & $\boldsymbol{p}$ value \\
\hline $\begin{array}{c}\text { Model constant } \\
\text { Dependent variable: ASWSC }\end{array}$ & -32.390 & 67.257 & -0.482 & 0.636 \\
Independent variables & & & & \\
Soil depth up to bedrock & 1.568 & 0.126 & 12.432 & $\mathbf{0 . 0 0 0}$ \\
Slope of soil profiles & 0.350 & 0.418 & 0.836 & 0.415 \\
Sand & 0.640 & 0.704 & 0.908 & 0.376 \\
Clay & 0.120 & 0.637 & 0.188 & 0.853 \\
Silt & 0.170 & 0.703 & 0.241 & 0.812 \\
Soil skeleton content & -0.834 & 0.099 & -8.421 & $\mathbf{0 . 0 0 0}$ \\
\hline
\end{tabular}

\subsection{Relation between ASWSC and Crown Dieback}

We found a significant and strong negative correlation between the magnitude of crown dieback and ASWSC (Spearman's rho $=-0.61, \mathrm{R}^{2}=0.39 p<0.001$ ) (Figure 1). This means that as the level of ASWSC increases, the crown dieback decreases in young beech plants. Crown dieback was significantly higher in dry plots (ASWSC $<61 \mathrm{~mm}$ ) than in less dry plots (ASWSC > $61 \mathrm{~mm}$ ) (Figure 2).

Figure 1. Relation between crown dieback, expressed by dead above ground biomass percentage and soil water stress calculated by the available soil water storage capacity (ASWSC in millimeters).

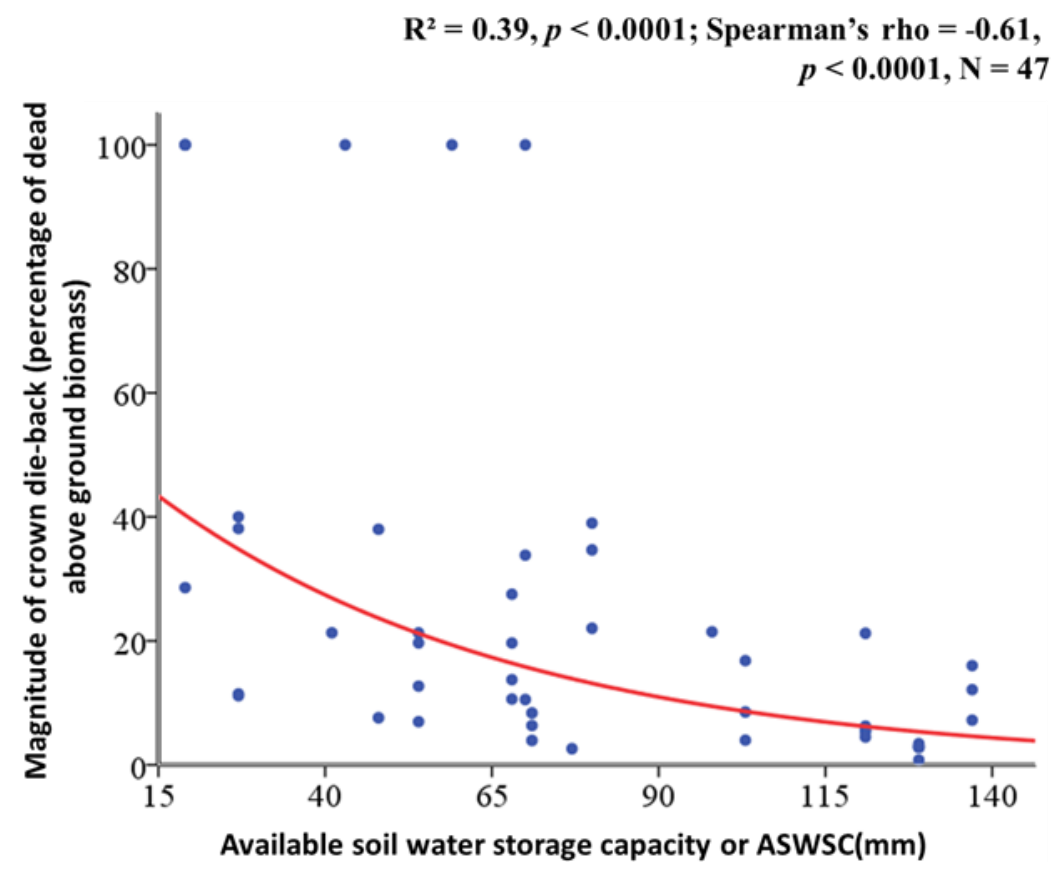


Figure 2. Magnitude of crown dieback (reported as median) was significantly higher among plants in dry plots (22\%) than less dry plots $(8 \%)$.

$$
\begin{array}{r}
\text { Mann-Whitney } U=106.00, p<0.001, \\
\mathrm{~N}_{\text {Dry plots }}=16, \mathrm{~N}_{\text {Less dry plots }}=31, \mathrm{~N}_{\text {Total }}=47
\end{array}
$$

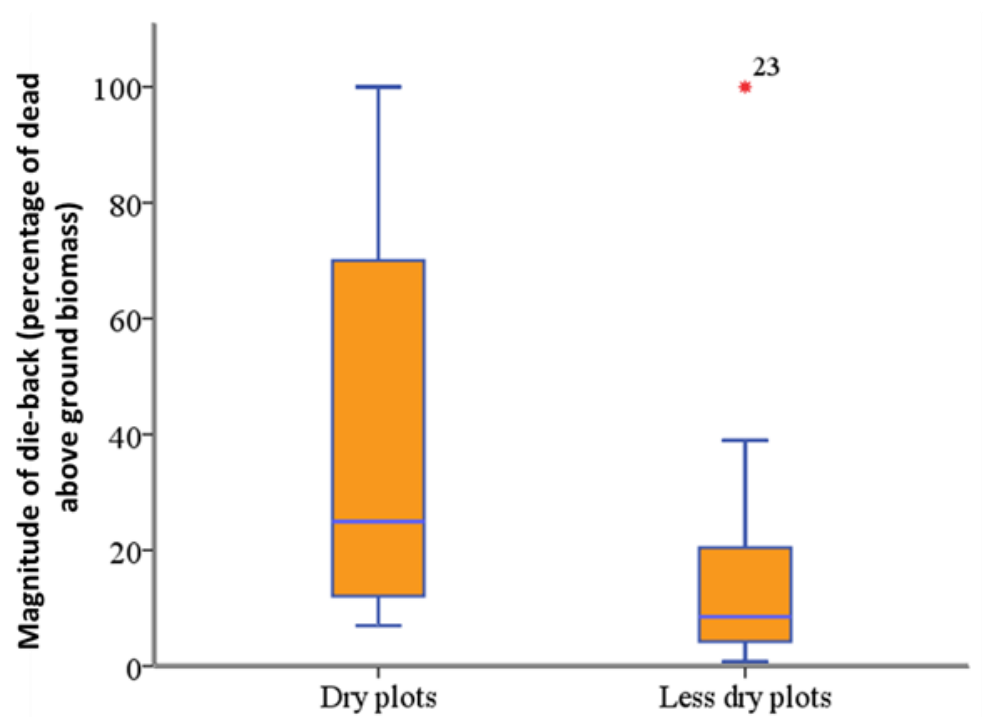

In this study, we found an interesting result regarding the crown dieback or mortality threshold in young beech plants. We did not find any single surviving plants in our total sample of 47 (42 live and five dead plants) that had more than $40 \%$ crown dieback. This means that irreversible damage had happened to the plant when dieback reached the threshold of $40 \%$, which eventually lead to the death of the whole plant (Figure 3). The probability of whole plant death increased significantly for the plants which were found in dry plots (see Table 2).

Figure 3. Mortality threshold of crown dieback, expressed by above ground dead biomass percentage for the young beeches in dry and less dry plots, expressed by available soil water storage capacity (ASWSC in millimeters). The figure shows the crown dieback threshold at $40 \%$.

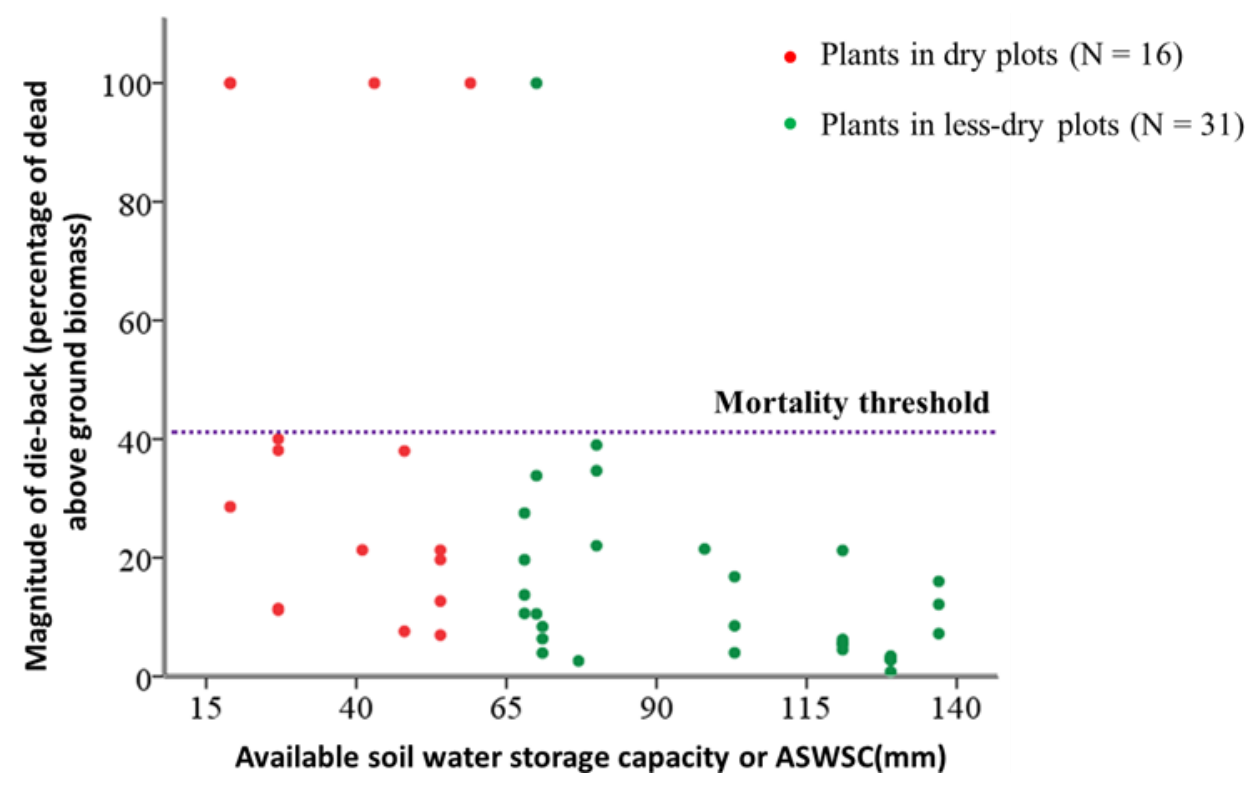


Table 2. Results from binary logistic regression, where a status plant (live or dead) was selected as dependent variable and ASWSC of plots (dry or less dry) was considered as independent variable (Log likelihood ratio value: 26.830, Cox and Snell $\mathrm{R}^{2}=0.101$, Nagelkerke $\mathrm{R}^{2}=0.206, \mathrm{~N}=47$ ).

\begin{tabular}{cccccc}
\hline Parameters & $\begin{array}{c}\text { Model } \\
\text { estimate }(\boldsymbol{\beta})\end{array}$ & $\begin{array}{c}\text { Standard error for } \\
\text { model estimate }\end{array}$ & $\begin{array}{c}\text { Wald Chi } \\
\text { square }\end{array}$ & $\boldsymbol{d f}$ & $\boldsymbol{p}$ value \\
\hline Less dry plots vs. Dry plots & -2.303 & 1.169 & 3.879 & 1 & 0.0389 \\
Model constant & 3.401 & 1.017 & 11.195 & 1 & 0.0008 \\
\hline
\end{tabular}

\subsection{Partial Dieback in Different Crown Compartments}

The magnitude of crown dieback was different in the three vertical crown compartments in both dry and less dry plots (Figure 4a). The lower crown was affected by the highest dieback in both plot groups (dry plots: 58\%; less dry plots: 53\%). In both dry and less dry plots, crown dieback was significantly lower in the upper crown compared to the rest of the crown (dry plots: $t=-5.144$, $d f=11, p<0.001, \mathrm{~N}=12$; less dry plots: $t=-5.981, d f=29, p<0.001, \mathrm{~N}=30$ ) (Figure 4b).

Figure 4. Magnitude of crown dieback in different vertical crown compartments of the dry and less dry plots. The pie-diagram (a) shows the percentage of crown dieback in plants from dry and less dry plots. The bar diagram (b) compares the percentages of crown dieback between upper crown and the rest of the crown (middle and lower combined) in dry and less dry plots. The thin bars represent the standard error of mean at a $95 \%$ confidence interval. Yellow and green asterisks show the significance level $(p<0.001)$.

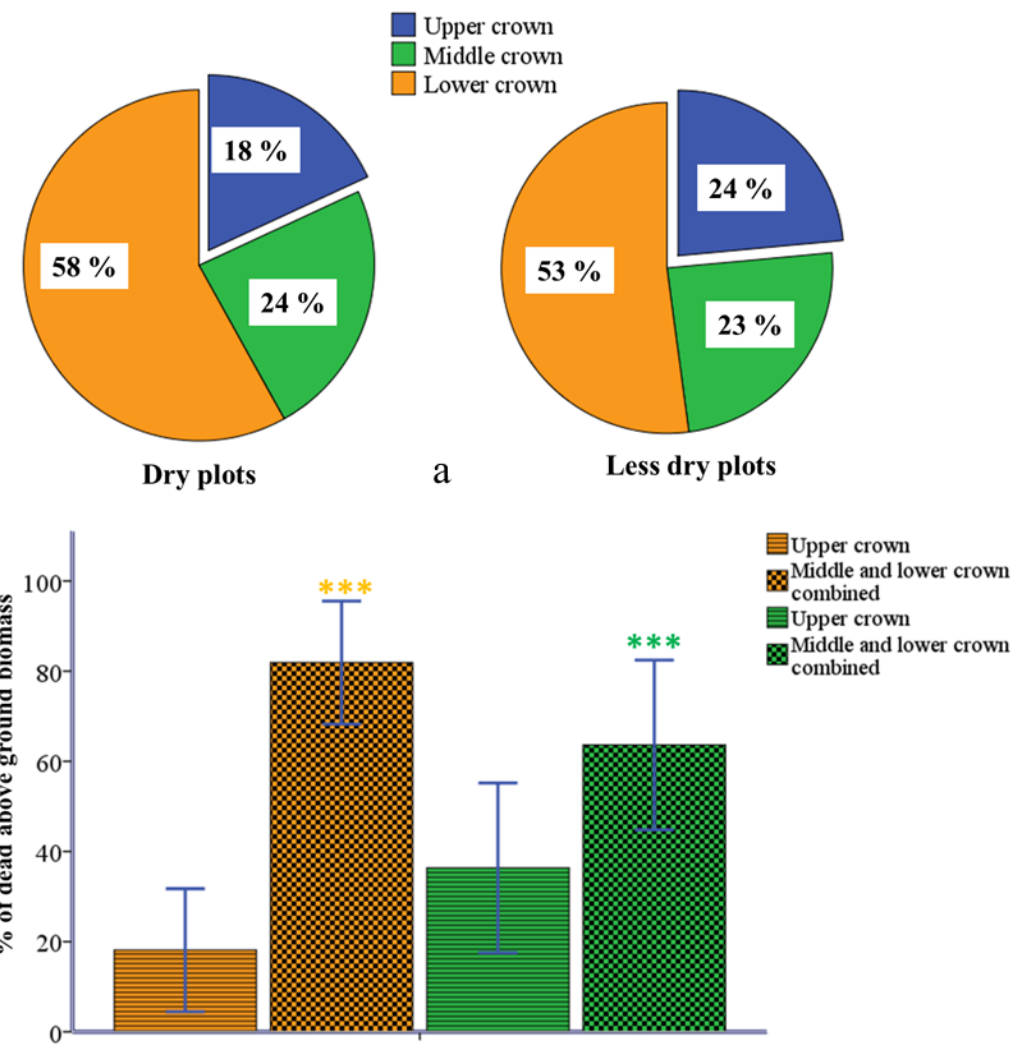

Dry plots

Less dry plots 


\subsection{Summer Drought of 2003 and Basal Area Increment}

The mean age of plants was 15 years and did not vary significantly between dry and less dry plots. The plants with root collar diameters of 3 to $6 \mathrm{~mm}$ had an average age of 6 years, whereas, the plants with 32 to $41 \mathrm{~mm}$ collar diameter had an average of 35 years (Figure 5). Out of 42 living plants, only four were born (two each in dry and less dry plots) in the drought year of 2003. Nevertheless, only one plant out of 42 (with $>1 \mathrm{~mm}$ root collar diameter) was born after the drought year of 2003. That single plant was found in a less dry plot.

Figure 5. Age and root collar diameter of sampled beech plants $(\mathrm{N}=42)$. Thin bars represent the standard error of mean at a $95 \%$ confidence interval.

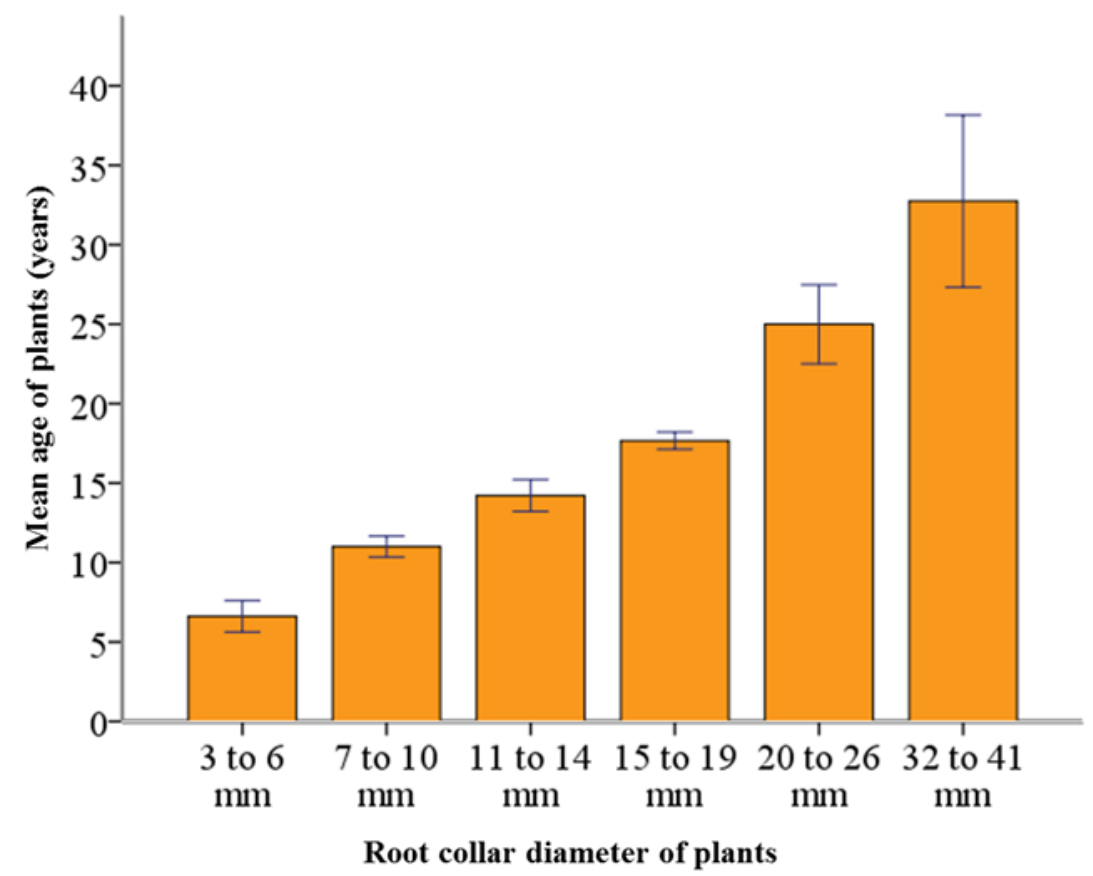

Older plants (17 to 30 years old, age Class I and II) from dry and less dry plots had followed similar trends in basal area increment until 2003. However, after the 2003 summer drought, plants from less dry plots were following higher slopes in growth trajectory compared to plants from dry plots in age Class I and II. Since year of 1999, slope of growth trajectory was higher in plants from less dry plots than dry plots in age class III. However, this trend could not be observed in very young plants (7 to 9 years of age) (Figure 6). 
Figure 6. Trends in basal area increments in 42 beech plants in four different age classes (Class I $=24$ to 30 year old, (a); Class II $=17$ to 23 year old, $(\mathbf{b})$; Class III $=10$ to 16 year old, (c); and Class IV $=7$ to 9 year old (d). The summer drought of 2003 was used as pointer year. Non-linear regression (after post hoc testing) with power function was used to report the strength in the growth trend.
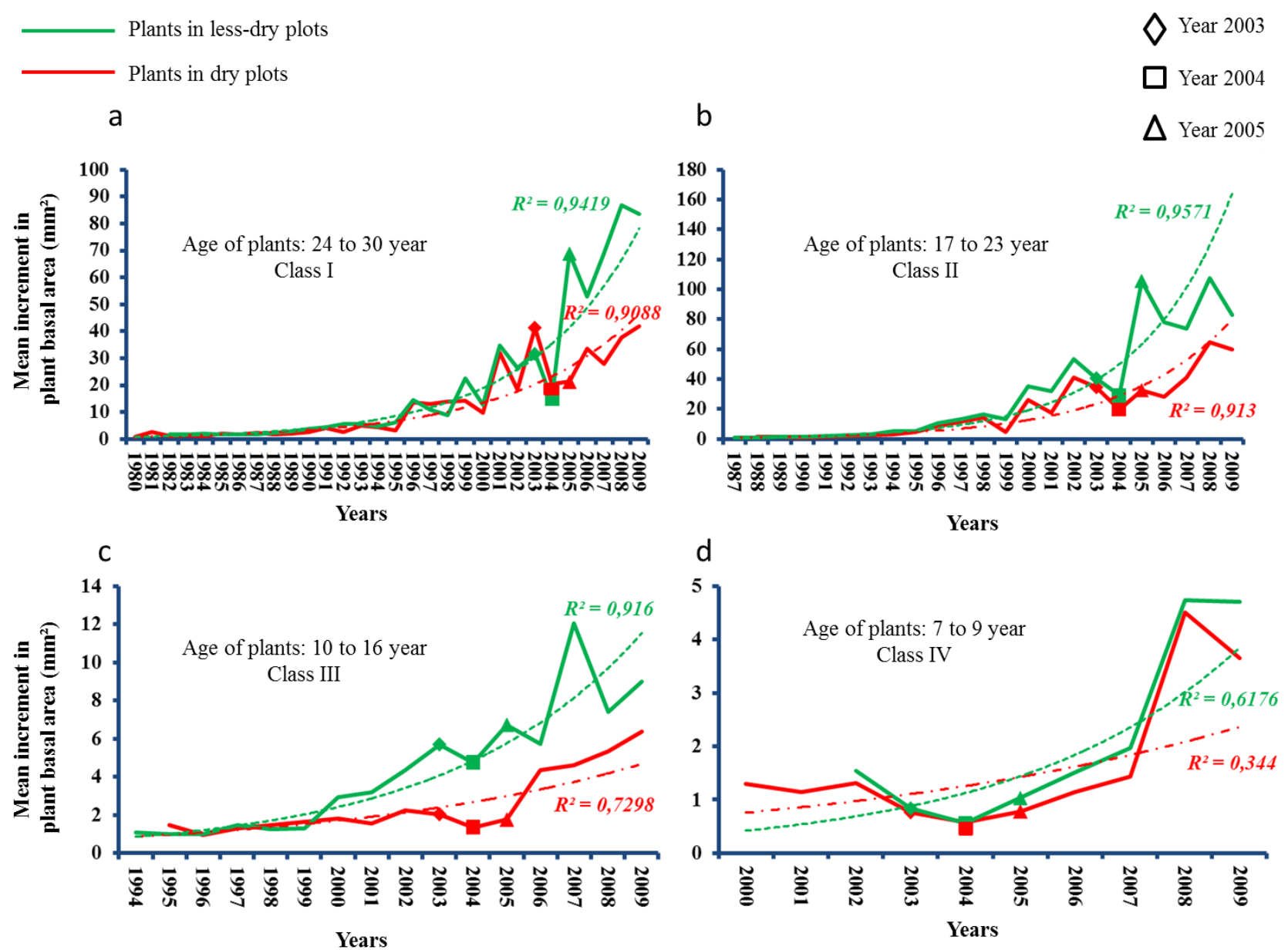

In both dry and less dry plots, there was a reduction of growth in 2004 compared to the previous drought year of 2003. This reduction was significant in dry plots but not in less dry plots (dry plots: $t=2.911, d f=11, p<0.05, \mathrm{~N}=12$; less dry plots: $t=1.581, d f=11, p>0.05, \mathrm{~N}=12)$. However, recovery in basal area growth from 2004 to 2005 was significantly higher among plants located in less dry plots. This growth recovery was not significant for plants in dry plots (dry plots: $t=2.911, d f=11$, $p<0.05, \mathrm{~N}=12$; less dry plots: $t=1.581, d f=11, p>0.05, \mathrm{~N}=12$ ). Overall, this meant that the 2003 summer drought had a higher negative impact on plants which were located in dry plots than on plants in less dry plots (Figure 7). 
Figure 7. Comparisons of basal area increments between the years of 2003, 2004 and 2005 in dry (red) and less dry plots (green). Asterisks denote the level of significance $(p<0.05)$. Thin bars indicate the standard error of mean at a $95 \%$ confidence interval.

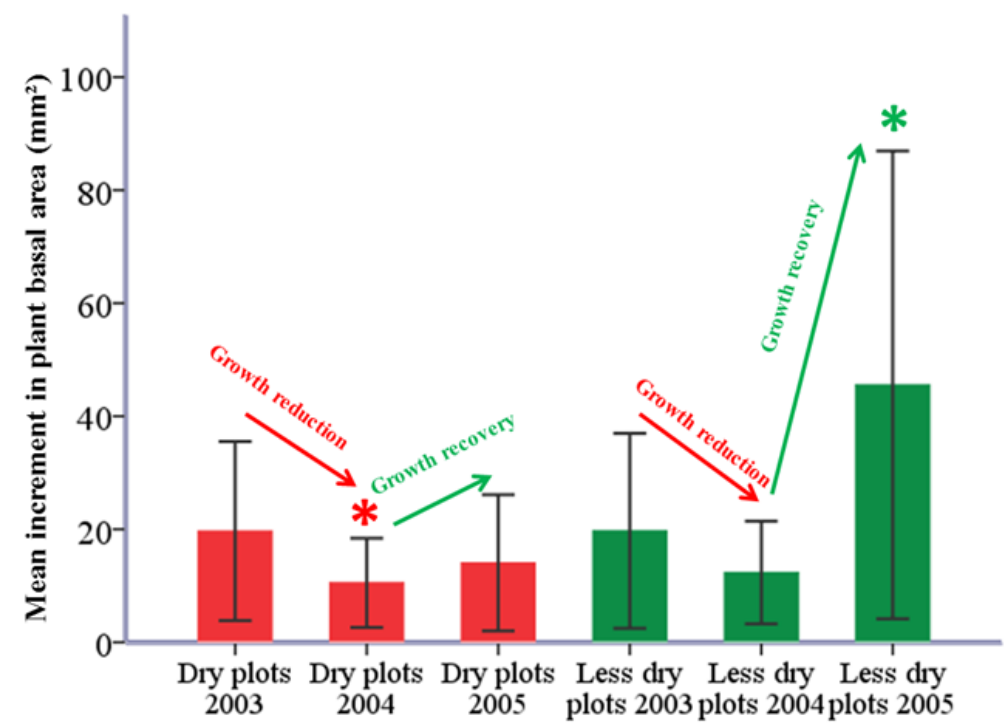

\section{Discussion}

In a dry stand with a mean ASWSC of $67 \mathrm{~mm}$, the magnitude of crown dieback significantly increased with a decrease in ASWSC. This is an agreement with our first hypothesis. This result corroborates previous studies which have found that under the prolong water stress, vitality decreases among trees in forests due to crown dieback [15]. We found that with an increase in soil water stress, the chance of survival of young beech plants diminished. This finding supports a previous study on oak trees, which showed that under chronic water stress in dry soil, the capability of young trees to overcome the stress or to survive diminished as their vitality decreased [21]. At a certain "point of no return", irreversible damage would occur, which could eventually lead to permanent tree death [15]. Our results on crown dieback threshold show for the first time that this "point of no return" for young (30 $\mathrm{cm}$ to $250 \mathrm{~cm}$ height) beech plants is a $40 \%$ dieback in the crowns in terms of above ground biomass.

Past studies have proven that forest stands with shallow soil and with high amounts of skeleton content have a high risk of water stress [12]. Water stress was found to be higher in such stands when they were located in the southwestern aspect as outcrop, hence, getting high solar exposure resulting in high evapotranspiration [14,16,22,23]. Gartner et al. working with various environmental, edaphic and topographical variables discovered that ASWSC would appear to be the most important limiting factor for beech survivability when it dropped below a threshold value of $68 \mathrm{~mm}$ at stand level [13]. The mean ASWSC in our stand was $67 \mathrm{~mm}$, which supported this earlier assumption. In this study, five dead beech plants were sampled, which might cross the resistance threshold of $40 \%$ crown dieback when irreversible damage occurred as the cumulative effect of prolonged water stress, high solar irradiation and a catastrophic drought year of 2003 [24]. Based on the decline spiral model [25], severe drought years such as 2003 can operate as a trigger ("initiating factor") that may ultimately lead to mortality in trees that are already under stress (by "predisposing factors" such as dry site conditions, 
here low ASWSC) and succumb to subsequent stem and root damage by biotic agents ("contributing factors" such as wood-boring insects, fungal pathogens etc.). Moreover, Pedersen (1998) argues that a "predisposing factor" and an "initiating factor" alone can lead to subsequent decline of tree vitality or to tree death. Vulnerability to tree death increased in this very dry stand, particularly after the extreme dry year of 2003 in the region, when the drought most likely acted as an initiating factor of mortality [5,21].

The magnitude of dieback varies in different crown compartments. The highest dieback, in both dry and less dry plots, was found in the middle and lower parts of the crown. Based on this finding, we rejected our second hypothesis. The middle and lower crown, which create the more shaded part of the whole crown, are less effective in photosynthesis in general. This may induce dieback patterns more severely affecting the middle and lower parts of the crown, which would be the first not to be supported in photosynthesis [26]. Our result is also corroborated with outcomes from past studies, which have shown that drought-induced cavitation and loss in hydraulic conductivity cause branch dieback that reduces the transpiration demand and thereby enabling the remaining shoots to maintain a favorable water balance $[18,19,27]$. Such an interpretation could be applied to many situations of growth decline in trees, e.g., where crown reductions or crown thinning resulting from branch abscission occurred after the onset of severe drought [28]. In addition to allowing dieback in lower parts of the crown under water stress, plants can regulate their root and shoot biomass and try to tune the root-shoot biomass ratio to maintain a specific correlation [29]. This strategy of root-shoot regulation in plants under prolonged water stress is called as "survival through dieback" [30]. In a dry year, parts of the tree dies back and only a few shoots survive, which are in balance with the root system. Branch dieback and the consequent reduction in whole plant leaf area are usually restricted to older and lateral twigs from the last order of branching. This would enable plants to adjust root-shoot ratios after drought induced decline in the root system, hence, crown dieback could be an acclimatization to drought stress [27,28,31]. Young beeches might choose a strategy of "survival through dieback" in this stand by allowing more branch dieback in lower parts of the crown and tuning root-shoot ratio [30]. However, they would not recover from this stress if they cross the threshold of $40 \%$ dieback in the crown in terms of above ground biomass.

Recovery in basal area increment after the drought year of 2003 was higher in plants from less dry plots than dry plots. This is an agreement with our third hypothesis. Our results prove that after a catastrophic drought event, plants growing in less dry plots have higher resistance (i.e., lower growth reduction) and better resilience (i.e., faster recovery in growth) than plants growing in dry plots. Differences in soil water availability explain why recovery of plants on dry plots was slower than less dry plots after the drought of 2003 [17]. The extreme drought of 2003 combined with the already existing water stress because of poor ASWSC at the study site had a strong negative impact on beech stem increment $[17,32,33]$. High temperatures accelerated the water deficiency from the soil, and this turned into a negative influence on the basal area increment of plants [15]. This problem became severe in dry plots as shown by our results. Czajkowski et al., who worked on the immediate impact of the 2003 summer drought on beech seedlings, reported that the plant water status during July and August of 2003 had a considerable effect on the relative increment of saplings in consecutive years [17]. This carry over effect observed by Czajkowski et al. corroborated our findings [17]. This phenomenon could be the consequence of high plasticity in broadleaved trees, which slowed down their growth to 
overcome the environmental stress in order to survive periods of poor growing conditions [34]. However, irreversible damage occurred if growth reduction led to crown dieback which in turn eventually forced the plants to cross the threshold.

\section{Experimental}

\subsection{Study Site and Sampling Design}

Data was collected in the summer of 2010 from a semi-natural sessile oak (Quercus petraea) stand (0.3 ha) with beech understory, surrounded by beech-dominated stands. The stand was located at Schlossberg hill in the Black Forest mountain region (near Freiburg city) in southwestern Germany $\left(47^{\circ} 59^{\prime} \mathrm{N}, 07^{\circ} 51^{\prime} \mathrm{E}\right)$ in the submontane zone at $400 \mathrm{~m}$ above sea level. Since the medieval period the stand had been managed under coppice with a standard silvicultural system in order to fulfill the firewood demand of the city of Freiburg. However, since the end of the Second World War, the stand remained unmanaged, all commercial activity had been permanently suspended and the forest was declared as a protected forest. Only recreational activities are permitted in the forest area. The stand is exposed to a slope in the south-west; hence, it receives high solar radiation throughout the whole vegetation period. The mean annual temperature and precipitation are $10^{\circ} \mathrm{C}$ and $930 \mathrm{~mm}$, respectively. The sessile oak stand is on the slope of a rocky gneiss outcrop that has shallow soils with a sandy texture and a high skeleton content. The mean slope of the stand is calculated to be $33.33^{\circ}$ (standard error: 4.67, $\mathrm{N}=24$ ). The soil contains a thin and uneven layer of humus or hagerhumus. Sometimes the mineral soil surface and bedrock (gneiss) are exposed, but in some places they are covered by moss (Figure 8).

Figure 8. Study site at Schlossberg (a), partially dead standing young understorey beech plant (b), sampled beech plant with a dead branch on the left and a living branch on the right side (c), shallow soil profile at the study plot (d).
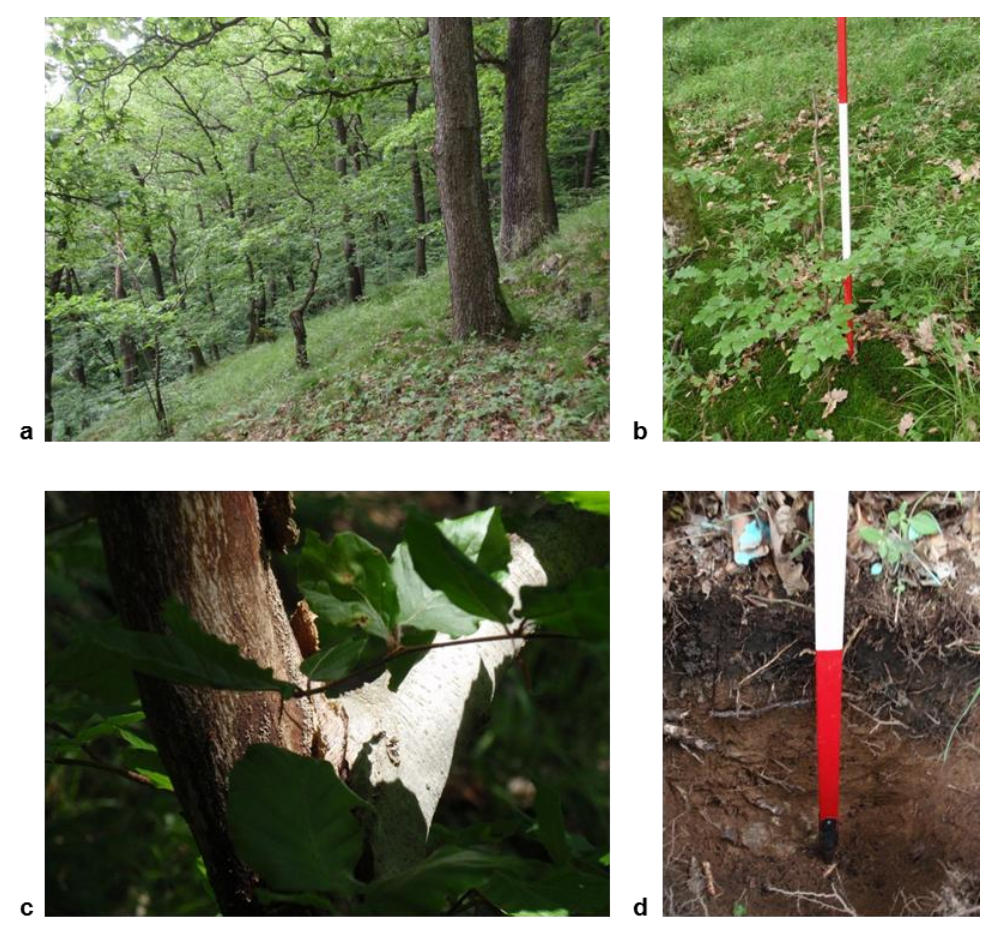
A systematic sampling design was followed for data collection in order to capture the gradient of ASWSC. The stand was small in size, and, therefore, negligible variations in environmental conditions (exposition, irradiation and/or light condition) among plots were assumed. Nevertheless, as beech is a shade tolerant species, competition for light is not a major constraint for tree establishment and survivability under the oak canopy [35]. A $54 \times 34 \mathrm{~m}$ rectangular borderline was selected inside the stand as the sampled area to establish the plots. A systematic grid of four rows and six vertical columns $10 \mathrm{~m}$ apart from one another was implemented in the rectangular design. Twenty-four circular sampling plots with a $2 \mathrm{~m}$ radius and a central point, with vertical and horizontal distances of $10 \mathrm{~m}$ from each other, were established [36].

\subsection{Collection of Morphological Data}

As we wanted to assess the impact of ASWSC on the establishment of European beech plants in the stand, we focused on young understorey beech plants with a height ranging from 30 to $250 \mathrm{~cm}$. In the German forest inventory system, a height of $250 \mathrm{~cm}$ for broadleaved plants is regarded as the threshold for successful establishment of natural regeneration [37]. Morphological and growth parameters were recorded for 47 young beech plants (42 live and five dead) found in the 24 circular plots. For the 42 living plants, the diameter at root collar $(5 \mathrm{~cm}$ above ground level) and the diameter of all living branches ( $>1.5 \mathrm{~mm}$ diameter) were measured, and the number of all living branches and annual shoots ( $<1.5 \mathrm{~mm}$ diameter) was counted. The crown was equally divided into three vertical parts, namely upper, middle and lower, starting from the first green branch as described by Kohler et al. [5]. Diameter and location of all dead branches in the three different crown compartments were recorded to quantify the dieback in different crown parts by using a biomass equation developed for the stand. Only the diameter at root collar ( $5 \mathrm{~cm}$ above ground level) was measured for the five dead beeches inside the plots.

\subsection{Collection of Soil Data and Quantification of ASWSC}

\subsubsection{Collection of Soil Data from Forest Stand}

One by one meter soil profiles were dug until they touched the bedrock in the center of all 24 sampling plots. The different horizons were designated; soil depth and percentage of soil skeleton of each mineral horizon were measured [38]. Colors of moist soil were recorded for each mineral horizon using Munsell ${ }^{\circledR}$ Soil Colour Charts [39]. Soil samples were collected from each mineral horizon of each soil profile for texture analysis.

\subsubsection{Quantification of ASWSC}

In this study, the magnitude of soil water stress was measured by ASWSC $[13,40]$. ASWSC is the maximum amount of fine earth available water, expressed in $\mathrm{mm} / 10 \mathrm{~cm}$. It is the difference between the water content values at field capacity and the permanent wilting point [41]. At first, collected samples were sieved using a $2 \mathrm{~mm}$ sieve to separate out gravels and stones. Then the soils were crushed using a mortar and pestle to mix the soil aggregates. Then sand, clay and silt fractions of the soil were determined by using an assessment of texture method developed by Food and Agriculture 
Organization of the United Nations, Working Group for Forest Site Classification of Germany, and Working Group on Soil Classification in Germany modified after Schack-Kirchner [42-45]. Both German and FAO texture classes were recorded. Soil organic matter content was calculated using the Munsell color of soil and soil texture class proposed by Schlichting et al. [39,46]. ASWSC was calculated in $\mathrm{mm}$ for each plot using soil horizon depth, soil skeleton content, soil texture, and soil organic matter content. ASWSC ranged from 19 to $137 \mathrm{~mm}$ for 24 plots. Twelve plots were classified

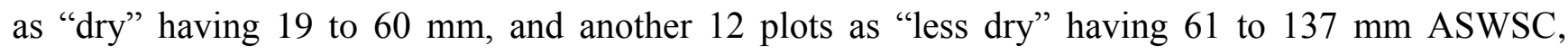
respectively (Table 3) [43]. Please see the detailed plot-wise calculation of ASWSC in the supplementary document namely "Quantification of ASWSC.xlsx" uploaded in Supplementary File 1.

Table 3. ASWSC of 24 plots in the stand.

\begin{tabular}{|c|c|c|c|c|c|}
\hline \multicolumn{3}{|c|}{ Dry plots } & \multicolumn{3}{|c|}{ Less dry plots } \\
\hline Serial no. & Plot no. & Plot ASWSC (mm) & Serial no. & Plot no. & Plot ASWSC (mm) \\
\hline 1 & $1 / 1$ & 22 & 1 & $1 / 5$ & 71 \\
\hline 2 & $1 / 2$ & 21 & 2 & $1 / 6$ & 68 \\
\hline 3 & $1 / 3$ & 41 & 3 & $2 / 3$ & 98 \\
\hline 4 & $1 / 4$ & 59 & 4 & $2 / 6$ & 70 \\
\hline 5 & $2 / 1$ & 52 & 5 & $3 / 1$ & 129 \\
\hline 6 & $2 / 2$ & 19 & 6 & $3 / 2$ & 103 \\
\hline 7 & $2 / 4$ & 27 & 7 & $3 / 3$ & 77 \\
\hline 8 & $2 / 5$ & 43 & 8 & $3 / 5$ & 80 \\
\hline 9 & $3 / 4$ & 54 & 9 & $4 / 1$ & 103 \\
\hline 10 & $3 / 6$ & 54 & 10 & $4 / 2$ & 121 \\
\hline 11 & $4 / 3$ & 27 & 11 & $4 / 4$ & 137 \\
\hline 12 & $4 / 6$ & 48 & 12 & $4 / 5$ & 93 \\
\hline \multicolumn{3}{|c|}{ average ASWSC 39} & \multicolumn{3}{|c|}{ average ASWSC 96} \\
\hline
\end{tabular}

\subsection{Quantification of Crown Dieback}

Crown dieback was measured as the percentage of above ground biomass. In this section we will describe the procedures and steps used to quantify crown dieback for beech plants in this study.

\subsubsection{Development of Allometric Equations for above Ground Biomass from Harvested Plants}

All 42 living beeches from the sample plots were harvested to develop allometric equations for quantitative biomass analysis (12 and 30 plants from dry and less dry plots, respectively). We created five diameter classes for branches based on the inventory (Section 4.2) as following: two to five millimeters, 5.1 to $8 \mathrm{~mm}, 8.1$ to $11 \mathrm{~mm}, 11.1$ to $18 \mathrm{~mm}$ and 18.1 to $41 \mathrm{~mm}$. In total 80 branches (40 from the dry area and 40 from the less dry area) were used for biomass calculation and were selected from these diameter classes. All above ground living parts of the sampled plants including stem and perennial branches with bark, annual shoots with buds and leaves were collected. Three annual shoots from each of the three crown compartments were randomly collected from each harvested plant. 
Biomass of harvested samples was assessed by ex situ weighing after oven drying in the laboratory at the temperature of $105{ }^{\circ} \mathrm{C}$ to constant weight. All fractions weights were determined to $\pm 0.1 \mathrm{~g}$ accuracy.

At first we performed post hoc model testing with 12 linear and nonlinear regression functions to develop equations for biomass. In those regression model tests, we used the weight of the branches as dependent variable and the diameter $(\mathrm{mm})$ of the respective branches as independent variables. Finally, we found that non-linear regression with power function could explain the maximum amount of variation (resulted in the highest $\mathrm{R}^{2}$ value) in the data. This also supported a recent study that had shown that the biomass of almost all European broadleaved tree species followed a non-linear power function relationship with the diameter in young stages [47]. Finally, two non-linear regression models were formulated with biomass and diameter separately for both dry (Figure 9a) and less dry (Figure 9b) plots, using the biomass of stems and perennial shoots, according to the following formula:

$$
\mathrm{Y}=\mathrm{a} \times \mathrm{d}^{\mathrm{b}}
$$

where $Y=$ biomass, $a=$ coefficient constant, $b=$ regression coefficient and $d=$ stem $/$ branch diameter.

Figure 9. Regression model for biomass equation of the dry (a) and less dry plots (b). Biomass (Y) is modeled as the power function of stem/branch diameter (d). Biomass was measured in gram and diameter in millimeter $(\mathrm{mm})$.
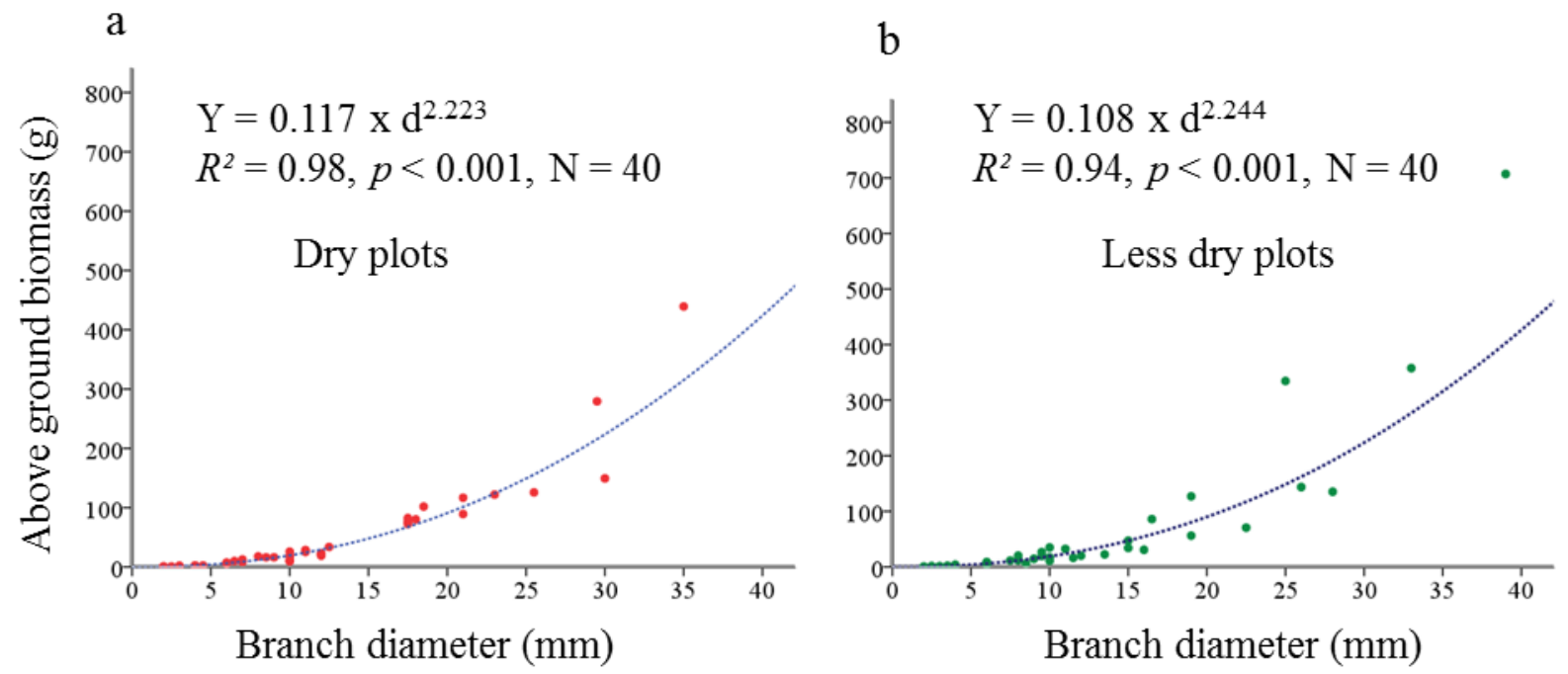

Mean of observed and modeled values from allometric equations were compared by $t$-test and showed no significant difference (Table 4). Hence, the allometric equations were accepted and used to calculate the biomass of branches in dry and less dry plots.

Table 4. Results of model testing for biomass equations (Figures 9a,b and 10) in dry and less dry plots.

\begin{tabular}{cccc}
\hline Statistical tests & Dry plots & Less dry plots & Dead tree \\
\hline \multirow{2}{*}{$t$-test } & $t(39)=0.72$ & $t(39)=1.24$ & $t(41)=-0.22$ \\
& $p>0.05$ & $p>0.05$ & $p>0.05$ \\
\hline
\end{tabular}


The average biomass of annual shoots with buds and leaves was calculated separately for both dry and less dry plots. Biomass of total annual shoots of each tree was calculated by multiplying the average number with the total number of annual shoots recorded during the field study. The weights of annual shoots were summed up with the branch weight in order to get the total above ground biomass. In addition to the two above-mentioned equations for the branches, we also developed a biomass equation for living plants based on the root collar diameter (Figure 10). We also performed a $t$-test between modeled and observed values for this equation and did not find any significant difference (Table 4).

Figure 10. Regression model for above ground biomass equation of the dead trees. Above ground biomass $(\mathrm{Y})$ is modeled as the power function of the diameter at root collar (d). Above ground biomass was measured in grams and the diameter at root collar in millimeters (mm).

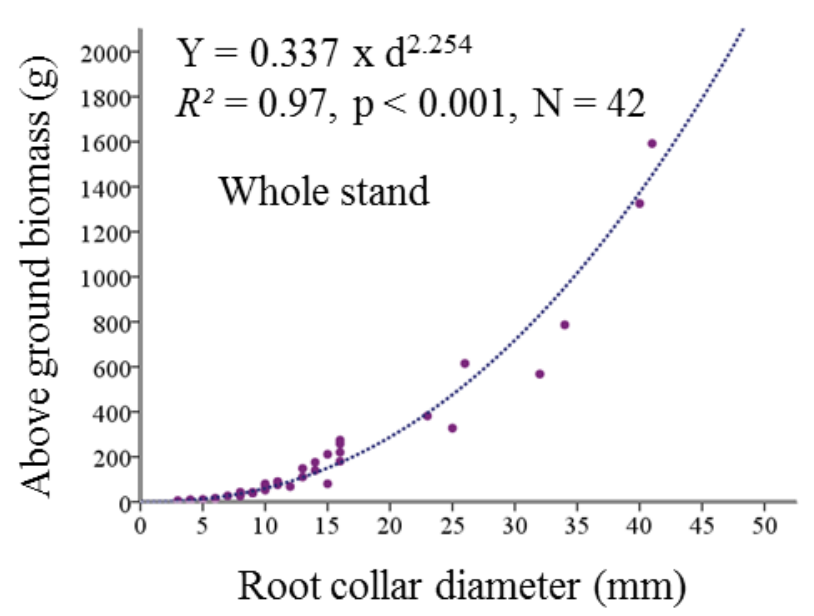

\subsubsection{Simulation of Dead above Ground Biomass}

Every living beech plant in our plots had dead branches or twigs. Those dead branches were either broken from the base or broken at a certain length from the base as a result of the branch shedding process. Practically, it was impossible to calculate the actual weight of that dead branch once it was green. We therefore developed a novel approach. We simulated the weight of a dead branch from the diameter recorded during field inventory. The diameter of such a dead branch was measured at the base where the mortality started and was still visible during the field inventory (Figure 11). Finally biomass of that dead branch was simulated from the allometric equations developed from the living branches of harvested plants specifically using the equation for dry and less dry plots. For a single tree, all dead branches were summed to calculate the total simulated weight of the dead branch. Similarly like the dead branches, above ground biomass of standing dead beech plants (five in total) were simulated from the regression model described in Figure 10. 


\subsubsection{Calculation of the Proportion Dead above Ground Biomass (Quantitative Estimation of Crown-Dieback)}

After we had calculated the total simulated dead above ground biomass and actual living biomass we made a simple proportion of these two biomass components in terms of percentages.

$$
\% \text { of dead above ground biomass }=(\mathrm{D} / \mathrm{C}) \times 100
$$

where $D=$ dead simulated biomass of a tree, $C=$ total above ground biomass of the tree. The increase in percentage values means an increase in crown dieback in terms of dead above ground biomass. For a tree without any mortality this proportion would be zero and for a totally dead tree this would be one hundred.

Figure 11. Schematic representation of the simulation method to quantify the crown dieback in terms of biomass.

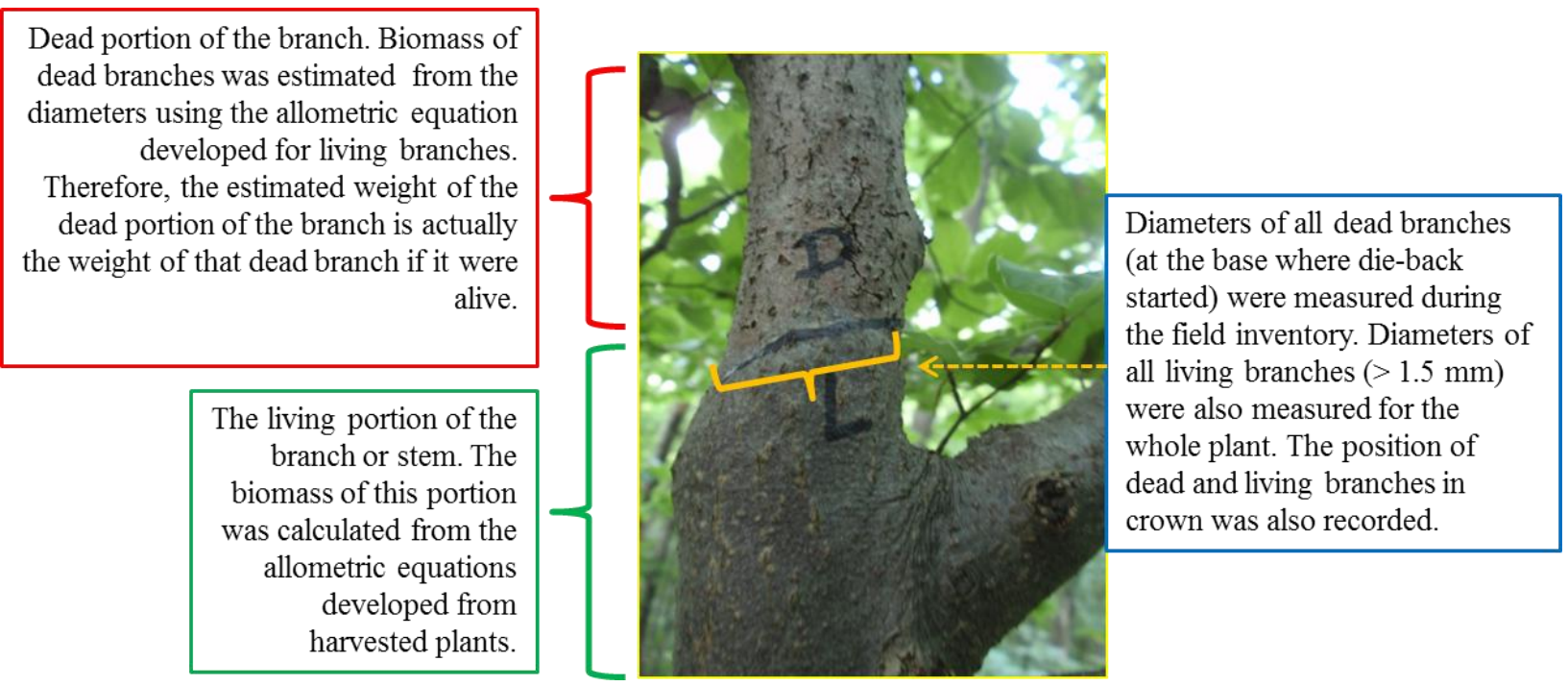

\subsection{Tree-Ring Analysis for Calculation of Basal Area Increment (BAI) for the Growth Study}

Tree-ring analysis was carried out using tree discs sampled at the root collar diameter at $5 \mathrm{~cm}$ above ground level. Stem discs from the 42 harvested plants were first used to calculate the age of the plants. After that, 24 plants (12 plants from dry plots and 12 from less dry plots) were selected to perform growth analysis. To minimize the confounding effect of the plant biological age on radial growth, we divided the plants in four age classes which were as follows: (1) Class I consisting of 24- to 30-year old plants; (2) Class II consisting of 17- to 23-year old plants; (3) Class III consisting of 10- to 16-year old plants; and (4) Class IV consisting of 7- to 9-years old plants. For every age class, we selected six plants (three plants in dry plots and three plants in less dry plots).

Samples were oven dried at $40{ }^{\circ} \mathrm{C}$ for 4 days and polished using successively finer sand paper to prepare them. Prepared samples were then scanned at 4,800 or 6,400 dpi using a LA1600+ scanner and saved as TIFF files (Figure 12). Ring boundaries were delimited manually on the images and ring widths were measured in four radial directions from the central pit to the periphery using the software WinDENDRO 2009 [48]. 
The ring width for each year was averaged from the four radial measurements to produce a final ring width series for each individual. Ring widths were converted into basal area increment (BAI), as this is more correlated with annual growth of the whole stem [49]. The following formula was used:

$$
\mathrm{BAI}=\pi\left(\mathrm{r}_{\mathrm{n}}^{2}-\mathrm{r}_{\mathrm{n}-1}^{2}\right)
$$

where $r=$ radius of the tree and $n=$ the year of tree ring formation, $\pi=3.14$.

As our sample plants were very young, the intension of the third objective of this study was not to correlate annual temperature and rainfall variation with growth increment in beeches, but rather to investigate the immediate impact of the severe drought of 2003 on the growth of young beech plants. For this reason, we focused on 2003 as the pointer year, as it has been proven to be a year of nationwide drought. Therefore, we did not calculate a water balance calendar for climatic drought but instead used the literature as a proof of the 2003 summer drought [3,5,50]. The growth reduction and recovery of the plants were calculated separately for both dry and less dry plots. The growth reduction was the difference in basal area increment between the drought year of 2003 and the year 2004 . Growth recovery was the increase in basal area increment from 2004 to 2005.

Figure 12. Stem discs for tree ring analysis, (a) 31-year-old beech plant with a root collar diameter of $33 \mathrm{~mm}$ from a less dry plot, (b) 42-year-old beech plant with a root collar diameter of $41 \mathrm{~mm}$ from a dry plot.

a

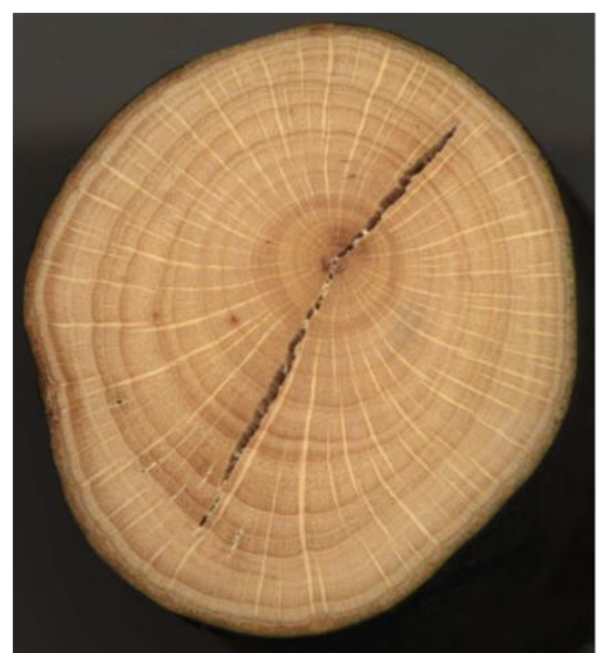

b

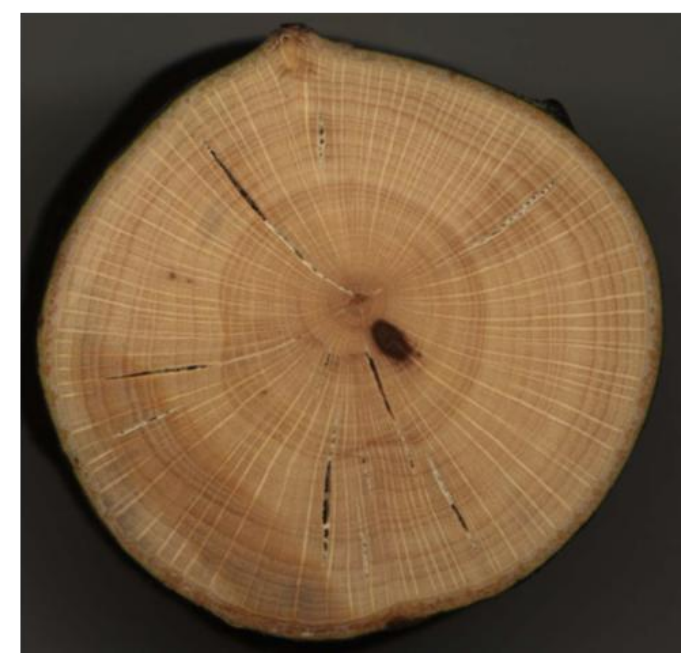

\subsection{Statistical Analyses}

\subsubsection{First Hypothesis}

At first we performed tests for normality (Kolomogorov-Smirnov test) on crown dieback (percentage of dead above ground biomass in 42 living plants and five completely dead but standing plants) and ASWSC of plots. We found that crown-dieback did not follow normal distribution, whereas, ASWSC followed normal distribution (see Normality Test 1 in Supplementary File 2). As data on crown dieback did not follow a normal distribution, we did non-parametric Spearman rank correlation tests to find the relationship between crown dieback and water stress (ASWSC). We did 
regression analysis to find whether crown-dieback could be explained by the variation in ASWSC. First we did post hoc regression analysis with 10 linear and nonlinear functions available in SPSS 20.0 [51], and selected an exponential function (non-linear) that explained the largest amount of variation (highest $\mathrm{R}^{2}$ ). To show whether the magnitude of crown dieback varied significantly between dry and less dry plots, a non-parametric Mann-Whitney $U$ test was performed. In addition, we performed a binary logistic regression analysis to find out whether the probability of whole plant mortality was significantly higher in dry plots compared to less dry plots.

\subsubsection{Second Hypothesis}

With this hypothesis we wanted to test whether the magnitude of crown dieback was significantly higher in the upper part of the crown compared to middle and lower parts. First, we used pie-diagrams to report the proportion of crown dieback (\%) in upper, middle and lower parts of the crown in dry and less dry plots. Then we combined dieback from the middle and lower crown and compared this the to upper part by paired sample $t$ test separately for dry and less dry plots. In this case we used parametric tests because dieback from the upper and remaining part of the crown was normally distributed in dry and less dry plots (see supplementary document uploaded in Supplementary File 2).

\subsubsection{Third Hypothesis}

We first plotted the mean annual basal area increment of plants from four age classes over time. In every age class, we fitted trend-lines separately for trees in dry and less dry plots. As exponential functions showed the highest $\mathrm{R}^{2}$ they were chosen to fit the trend-line in the basal area increment curve. Our intention by fitting trend-lines to the basal area increment curves was to check whether there was any difference in trends among plant growths over time in dry and less dry plots. To test whether the 2003 summer drought had a significant impact on growth reduction and recovery in plants, we did paired sample $t$ tests between the mean basal area increments in 2003, 2004 and 2005. Mean basal area increments from both dry and less dry plots were normally distributed in those three years (see Supplementary File 2).

\subsubsection{Factors Influencing ASWSC}

We wanted to find important soil and stand parameters (e.g., soil depth up to bed rock, slope of soil profiles, content of sand, clay, silt and soil skeleton), which had significant influence on the magnitude of ASWSC. The ASWSC was normally distributed (see Section 4.6.1). We also did normality tests for other parameters and found that all parameters followed a normal distribution (see Normality Test 4 in Supplementary File 2).

As our data of the ASWSC, slope and other soil parameters were normally distributed we performed linear regression analysis. We used ASWSC as dependent variable and slope and other soil parameters as independent variable. All statistical analyses were done by SPSS v.20 [51]. 


\section{Conclusions}

We conclude that soil water stress (very low ASWSC) increases crown dieback, and hence, reduces tree vitality in a dry gneiss south-facing outcrop in the Black Forest. The threshold of crown dieback was found to be $40 \%$ in that semi-natural forest stand, which has not been under commercial management since the end of the Second World War. However, whether this threshold is consistent to a larger geographical scale in dry beech forest stands should be researched in future studies involving multiple sites. In addition, physiological processes behind this mortality threshold of young beech trees warrant further investigation.

In the future, an increased frequency of climatic drought might turn lethal for beeches on shallow soils where soil water stress is prevalent and could act as pre-disposing factor of tree mortality as an aftershock of one or multiple severe drought events [21]. Nevertheless, our study highlights the importance of causes and consequences of tree mortality in a dry site with shallow soil in a temperate forest.

Drought could lead to major compositional changes in plant species [52]. This in turn could initiate the development of new forest ecosystems due to new combinations of native and invasive exotic trees depending on the climatic and edaphic tolerances of seedlings [53,54]. This is a dynamic and long-term process which warrants further investigation, particularly near the distribution limits of beech forests on dry sites.

\section{Acknowledgments}

Tamalika Chakraborty gratefully acknowledges the Heinrich-Böll-Stiftung e.V for awarding the scholarship. We are thankful to Carl Burhop for providing voluntary support in soil profile digging. We are also grateful to the City Forest Administration of Freiburg for giving kind permission for working in the forest, digging soil profiles, and harvesting 42 beech plants. We sincerely thank two anonymous reviewers who provided valuable suggestions and constructive criticisms that significantly improved the final version of the manuscript.

\section{Contributions of Co-Authors}

Tamalika Chakraborty and Albert Reif jointly developed the research concept and study designs. Albert Reif provided supervision to the first author. Somidh Saha helped in field data collection and provided statistical consultations on biomass and data analysis. Tamalika Chakraborty collected field data, performed all laboratory and statistical analysis. Tamalika Chakraborty and Somidh Saha wrote the manuscript.

\section{Conflicts of Interest}

The authors declare no conflict of interests. 


\section{References}

1. IPCC. Climate Change 2007: The Physical Science Basis; Intergovernmental Panel on Climate Change: New York, NY, USA, 2007; p. 996.

2. Mayer, H.; Holst, T.; Brugger, U.; Kirchassner, A. Trends of the forest significant climate variables air temperature and precipitation in south-west Germany from 1950 to 2000. Allgemeine Forstund Jagd-Zeitung 2005, 176, 45-56.

3. Ciais, P.; Reichstein, M.; Viovy, N.; Granier, A.; Ogee, J.; Allard, V.; Aubinet, M.; Buchmann, N.; Bernhofer, C.; Carrara, A.; et al. Europe-wide reduction in primary productivity caused by the heat and drought in 2003. Nature 2005, 437, 529-533.

4. Anderegg, W.R.L.; Berry, J.A.; Field, C.B. Linking definitions, mechanisms, and modeling of drought-induced tree death. Trends Plant Sci. 2012, 17, 693-700.

5. Kohler, M.; Kockemann, B.; Peichl, M.; Schmitt, J.; Reif, A. Impacts of the drought 2003 on the crown condition of suppressed and intermediate beech trees (Fagus sylvatica L.) at the ecotone between beech and downy oak forest in the nature reserve Innerberg, Sudbaden. Allgemeine Forst- und Jagd-Zeitung 2006, 177, 86-90.

6. Allen, C.D.; Macalady, A.K.; Chenchouni, H.; Bachelet, D.; McDowell, N.; Vennetier, M.; Kitzberger, T.; Rigling, A.; Breshears, D.D.; Hogg, E.H.; et al. A global overview of drought and heat-induced tree mortality reveals emerging climate change risks for forests. For. Ecol. Manag. 2010, 259, 660-684.

7. Brodribb, T.J.; Bowman, D.; Nichols, S.; Delzon, S.; Burlett, R. Xylem function and growth rate interact to determine recovery rates after exposure to extreme water deficit. New Phytol. 2010, $188,533-542$.

8. Coll, L.; Balandier, P.; Picon-Cochard, C.; Prevosto, B.; Curt, T. Competition for water between beech seedlings and surrounding vegetation in different light and vegetation composition conditions. Ann. For. Sci. 2003, 60, 593-600.

9. Lebourgeois, F.; Breda, N.; Ulrich, E.; Granier, A. Climate-tree-growth relationships of European beech (Fagus sylvatica L.) in the French Permanent Plot Network (RENECOFOR). Trees Struct. Funct. 2005, 19, 385-401.

10. Robson, T.M.; Rodriguez-Calcerrada, J.; Sanchez-Gomez, D.; Aranda, I. Summer drought impedes beech seedling performance more in a sub-Mediterranean forest understory than in small gaps. Tree Physiol. 2009, 29, 249-259.

11. Van Hees, A.F.M. Growth and morphology of pedunculate oak (Quercus robur L.) and beech (Fagus sylvatica L.) seedlings in relation to shading and drought. Ann. Sci. For. 1997, 54, 9-18.

12. Jump, A.S.; Hunt, J.M.; Penuelas, J. Rapid climate change-related growth decline at the southern range edge of Fagus sylvatica. Glob. Chang. Biol. 2006, 12, 2163-2174.

13. Gartner, S.; Reif, A.; Xystrakis, F.; Sayer, U.; Bendagha, N.; Matzarakis, A. The drought tolerance limit of Fagus sylvatica forest on limestone in southwestern Germany. J. Veg. Sci. 2008, 19, 757-768.

14. Topoliantz, S.; Ponge, J.F. Influence of site conditions on the survival of Fagus sylvatica seedlings in an old-growth beech forest. J. Veg. Sci. 2000, 11, 369-374. 
15. Dobbertin, M. Tree growth as indicator of tree vitality and of tree reaction to environmental stress: A review. Eur. J. For. Res. 2005, 124, 319-333.

16. Seletkovic, I.; Potocic, N.; Ugarkovic, D.; Jazbec, A.; Pernar, R.; Seletkovic, A.; Benko, M. Climate and relief properties influence crown condition of common beech (Fagus sylvatica $\mathrm{L}$.) on the Medvednica massif. Period. Biol. 2009, 111, 435-441.

17. Czajkowski, T.; Kuhling, M.; Bolte, A. Impact of the 2003 summer drought on growth of beech sapling natural regeneration (Fagus sylvatica L.) in north-eastern Central Europe. Allgemeine Forst- und Jagd-Zeitung 2005, 176, 133-143.

18. Rood, S.B.; Patino, S.; Coombs, K.; Tyree, M.T. Branch sacrifice: Cavitation-associated drought adaptation of riparian cottonwoods. Trees Struct. Funct. 2000, 14, 248-257.

19. Anderegg, W.R.L.; Anderegg, L.D.L. Hydraulic and carbohydrate changes in experimental drought-induced mortality of saplings in two conifer species. Tree Physiol. 2013, 33, 252-260.

20. Puettmann, K.; Coates, K.D.; Messier, C. A Critique of Silviculture: Managing for Complexity; Island Press: Washington, DC, USA, 2009; p. 189.

21. Pedersen, B.S. The role of stress in the mortality of midwestern oaks as indicated by growth prior to death. Ecology 1998, 79, 79-93.

22. Bolte, A.; Czajkowski, T.; Kompa, T. The north-eastern distribution range of European beech-A review. Forestry 2007, 80, 413-429.

23. Ellenberg, H. Vegetation Ecology of Central Europe; Cambridge University Press: Cambridge, UK, 1988.

24. Larcher, W. Plant Ecophysiology; Ulmer Verlag: Stuttgart, Germany, 2001.

25. Manion, P.D. Tree Disease Concepts; Prentice Hall: Englewood Cliffs, NJ, USA, 1981.

26. Cochard, H.; Lemoine, D.; Dreyer, E. The effects of acclimation to sunlight on the xylem vulnerability to embolism in Fagus sylvatica L. Plant Cell Environ. 1999, 22, 101-108.

27. Breda, N.; Huc, R.; Granier, A.; Dreyer, E. Temperate forest trees and stands under severe drought: A review of ecophysiological responses, adaptation processes and long-term consequences. Ann. For. Sci. 2006, 63, 625-644.

28. Rust, S.; Roloff, A. Acclimation of crown structure to drought in Quercus robur L.-intra- and inter-annual variation of abscission and traits of shed twigs. Basic Appl. Ecol. 2004, 5, 283-291.

29. Schulze, E.-D.; Beck, E.; Muller-Hohenstein, K. Plant Ecology; Springer: Berlin/Heidelberg, Germany, 2005; p. 702.

30. Evenari, M.; Shanan, L.; Tadmor, N. The Negev: The Challenge of a Desert; Harvard University Press: Cambridge, MA, USA, 1982; p. 437.

31. Rust, S.; Roloff, A. Reduced photosynthesis in old oak (Quercus robur): The impact of crown and hydraulic architecture. Tree Physiol. 2002, 22, 597-601.

32. Eckstein, D.; Richter, K.; Aniol, R.W.; Quiehl, F. Dendroclimatological investigations of the beech decline in the southwestern part of the Vogelsberg (Hesse, West-Germany). Forstwissenschaftliches Centralblatt 1984, 103, 274-290.

33. Leuschner, C.; Backes, K.; Hertel, D.; Schipka, F.; Schmitt, U.; Terborg, O.; Runge, M. Drought responses at leaf, stem and fine root levels of competitive Fagus sylvatica L. and Quercus petraea (Matt.) Liebl. trees in dry and wet years. For. Ecol. Manag. 2001, 149, 33-46.

34. Brubaker, L.B. Responses of tree populations to climatic-change. Vegetatio 1986, 67, 119-130. 
35. Von Lüpke, B. Silvicultural methods of oak regeneration with special respect to shade tolerant mixed species. For. Ecol. Manag. 1998, 106, 19-26.

36. Chakraborty, T. Effect of Soil Drought on Vitality and Growth on Juvenile and Understorey Beech (Fagus sylvatica L.) Trees: Case Study from a Rocky Gneiss Outcrop near Freiburg, Black Forest, Germany. Master Thesis, Albert-Ludwigs-University of Freiburg, Freiburg, Germany, 2010. Available online: http://www.freidok.uni-freiburg.de/volltexte/8066/ (accessed on 17 October 2013).

37. FVA. Aufnahmeanweisung und Verfahrensbeschreibung permanente Betriebsinventur pBle + pBlf (Guidebook for Doing Forest Inventory, in German); Forstliche Versuchs- und Forschungsanstalt Baden-Württemberg: Freiburg, Germany, 2004.

38. Hodgson, J.M. Soil Survey Field Handbook; Soil Survey of England and Wales, Rothamsted Experimental Station: Harpenden, UK, 1974; Volume 5.

39. Munsell, A.H. Munsell Soil Color Charts, Revised ed.; MacBeth Divisionof Kollmorgen Instruments Corp: New Windsor, NY, USA, 1994.

40. Sayer, U. Die Ökologie der Flaumeiche (Quercus pubescens Willd.) und ihrer Hybriden auf Kalkstandorten an ihrer nördlichen Arealgrenze (Untersuchungen zu Boden, Klima und Vegetation); Cramer: Stuttgart, Germany, 2000; Volume 340, p. 198.

41. Samaras, D. The Vegetation of Greek Fir (Abies cephalonica Loudon) Forests on the Oxia-North Vardousia Mountain System, Central Greece, in Relation to Drought. Ph.D. Thesis, Albert Ludwigs University of Freiburg, Freiburg, Germany, 2012. Available online: http://www.freidok.unifreiburg.de/volltexte/8642/ (accessed on 17 October 2013).

42. FAO. Guidelines for Soil Description; Food and Agriculture Organization of the United Nations: Rome, Italy, 2006.

43. Arbeitskreis Standortskartierung. Forstliche Standortsaufnahme, 6th ed.; IHW-Verlag und Verlagsbuchhandlung: Munich, Germany, 2003.

44. AG Boden. Bodenkundliche Kartieranleitung: Arbeitsgruppe Boden, 4th ed.; Schweizerbart Verlag: Stuttgart, Germany, 1994.

45. Schack-Kirchner, H. Ein Fuzzy-Schlüssel für die Texturschätzung mit der Fingerprobe; Fakultät der Albert-Ludwigs-Universität und Forstliche Versuchs- und Forschungsanstalt, Freiburger Forstliche Forschung, Baden-Württemberg: Freiburg, Germany, 2001.

46. Schlichting, E.; Blume, H.-P.; Stahr, K. Bodenkundliches Praktikum. Eine Einführung in pedologisches Arbeiten für Ökologen, insbesondere Land- und Forstwirte und für Geowissenschaftler, 2nd ed.; Blackwell Wissenschafts-Verlag: Berlin, Germany, 1995.

47. Zianis, D.; Muukkonen, P.; Makipaa, R.; Mencuccini, M. Biomass and stem volume equations for tree species in Europe. Silva Fenn. Monogr. 2005, 4, 5-63.

48. WinDENDRO: Tree Ring, Stem, Wood Density Analysis and Measurement; Regent Inc.: Quebec City, QC, Canada, 2009.

49. Leblanc, D.C. Relationships between breast-height and whole-stem growth indexes for red spruce on Whiteface Mountain, New-York. Can. J. For. Res. 1990, 20, 1399-1407.

50. Rebetez, M.; Mayer, H.; Dupont, O.; Schindler, D.; Gartner, K.; Kropp, J.P.; Menzel, A. Heat and drought 2003 in Europe: A climate synthesis. Ann. For. Sci. 2006, 63, 569-577.

51. IBM Corporation. IBM SPSS Advanced Statistics 20; IBM Corporation: New York, USA, 2011. 
52. Rich, P.M.; Breshears, D.D.; White, A.B. Phenology of mixed woody-herbaceous ecosystems following extreme events: Net and differential responses. Ecology 2008, 89, 342-352.

53. Millar, C.I.; Stephenson, N.L.; Stephens, S.L. Climate change and forests of the future: Managing in the face of uncertainty. Ecol. Appl. 2007, 17, 2145-2151.

54. Suarez, M.L.; Ghermandi, L.; Kitzberger, T. Factors predisposing episodic drought-induced tree mortality in Nothofagus - Site, climatic sensitivity and growth trends. J. Ecol. 2004, 92, 954-966.

(C) 2013 by the authors; licensee MDPI, Basel, Switzerland. This article is an open access article distributed under the terms and conditions of the Creative Commons Attribution license (http://creativecommons.org/licenses/by/3.0/). 